\section{New Foliar-applied Biofilm Had No Impact on Splitting or Fruit Quality in 'Elliott' and 'Legacy' Blueberry in Oregon}

\author{
Amanda J. Vance ${ }^{1,3}$ and Bernadine C. Strik ${ }^{2,4,5}$
}

AdDITIONAL INDEX WORDS. Vaccinium corymbosum, berry firmness, shelf-life, storage, chemigation, Parka

SUMMARY. Fresh market blueberry (Vaccinium sp.) sales require high-quality, firm fruit with no significant defects. A new phospholipid biofilm product was developed to reduce splitting and increase firmness when applied directly to blueberry fruit. Two trials were undertaken to test the effects of the biofilm using various application timings and methods. In highbush blueberry cultivar Elliott (Vaccinium corymbosum), four treatments included: 1) rate and timing on the current product label ( 5 - to $10-\mathrm{mm}$ berry size, $10 \%$ to $20 \%$ color change, and between the first and second harvests), 2) addition of a preharvest timing (5- to $10-\mathrm{mm}$ berry size, $10 \%$ to $20 \%$ color change, and 7 to 10 days preharvest); 3 ) starting applications later $(10 \%$ to $20 \%$ color change, 7 to 10 days preharvest, and between the first and second harvests), and 4) a water-sprayed control. Biofilm was applied at a rate of $2 \mathrm{qt} /$ acre for all applications. In highbush blueberry cultivar Legacy (Vaccinium corymbosum $\times$ Vaccinium sp.), the same volume of biofilm was applied via an airblast sprayer or through an overhead sprinkler system typically used for chemigation and compared with a water-sprayed control. Data collected included yield (in 'Elliott'), berry weight, firmness, skin toughness, total soluble solids (TSS), weight loss during storage, percent splitting (in 'Legacy'), and a visual rating, evaluated on the day of harvest and about 14 and 28 days postharvest. There were no visual defects caused by application of biofilm. Compared with the controls in either study, biofilm had no consistent impact on fruit quality, firmness, shelf life, yield in 'Elliott', or splitting in 'Legacy'.

$\mathrm{T}$ The Pacific northwestern United States is an important production region for northern highbush blueberry, with 25,300 acres in production in Oregon and Washington in 2016 (U.S. Department of Agriculture, 2017). Of the total blueberry production, $34 \%(\approx 80$ million pounds) was sold to fresh markets, where fruit quality and shelf life are critical. In particular, firmness is an important aspect of fruit quality that is valued by growers, as it can extend the window of time in which fruit can be harvested, potentially allowing for machine harvest for fresh market and helping retain quality during shipping

We appreciate funding from the Clackamas County Innovative Grant Fund and Cultiva (Las Vegas, NV) as well as our grower collaborator PanAmerican Berry Growers (Salem, OR)

${ }^{1}$ Department of Horticulture and the North Willamette Research \& Extension Center, Oregon State University, 4017 ALS, Corvallis, OR 97331

${ }^{2}$ Department of Horticulture, Oregon State University, 4017 ALS, Corvallis, OR 97331

${ }^{3}$ Senior Faculty Research Assistant I.

${ }^{4}$ Professor.

${ }^{5}$ Corresponding author. E-mail: bernadine.strik@ oregonstate.edu.

https://doi.org/10.21273/HORTTECH04196-18
(Xu et al., 2015). Firmness is also important to packers and consumers as an indicator of quality (Ehlenfeldt and Martin, 2002; Moggia et al., 2017). However, a connection has been shown in rabbiteye (Vaccinium virgatum) and southern highbush (interspecific hybrids of Vaccinium sp.) blueberries between greater firmness and a greater incidence of fruit splitting (Marshall et al., 2008).

Berry splitting hastens the process of desiccation and necrosis, increases the risk of postharvest fruit rot, and most often requires fruit either to be diverted from fresh to processed markets or can render the fruit completely unmarketable. In rabbiteye blueberry, splitting can reduce marketable yield by up to $20 \%$ in some cultivars (Marshall et al., 2006, 2007). The most commonly grown cultivars in the Pacific northwestern United States are northern highbush blueberry, which have a low incidence of splitting in this region due to little rainfall during the summer months.

'Legacy', a hybrid of northern and southern highbush blueberry (Vorsa, 1998), has rapidly gained in popularity because of its high yield, desirable fruiting season, and excellent flavor. However, this cultivar has a greater tendency to split due its southern highbush heritage (Marshall et al., 2008), especially after a rainfall or overhead irrigation event. Although 'Elliott' does not typically split in this region, it is less firm than many other commonly grown cultivars (Yang et al., 2009) and has been found to split in some other production regions such as southern Chile (B.C. Strik, personal observation).

The biofilm (Parka; Cultiva, Las Vegas, NV) was developed and patented by Oregon State University for use in sweet cherry (Prunus avium) to reduce fruit splitting (referred to as "cracking" in cherries) when applied preharvest (Kaiser et al., 2014). The product is a wax-based, food-grade phospholipid biofilm applied to foliage and fruit intended to supplement the fruit's surface cuticle and allow for increased elasticity and reduced cracking. During initial testing, it also advanced maturity (increased TSS and color) in some cases (Kaiser et al., 2014). The technology was further developed by the manufacturer for use in other crops, including blueberry. When the biofilm was tested in 2013 and 2015 on

\begin{tabular}{llll}
\hline $\begin{array}{l}\text { Units } \\
\begin{array}{l}\text { To convert U.S. to SI, } \\
\text { multiply by }\end{array}\end{array}$ & U.S. unit & SI unit & $\begin{array}{l}\text { To convert SI to U.S., } \\
\text { multiply by }\end{array}$ \\
\hline 0.4047 & acre $(\mathrm{s})$ & $\mathrm{ha}$ & 2.4711 \\
0.3048 & $\mathrm{ft}$ & $\mathrm{m}$ & 3.2808 \\
3.7854 & $\mathrm{gal}$ & $\mathrm{L}$ & 0.2642 \\
9.3540 & gal/acre & $\mathrm{L} \cdot \mathrm{ha}^{-1}$ & 0.1069 \\
25.4 & inch $(\mathrm{es})$ & $\mathrm{mm}$ & 0.0394 \\
0.4536 & $\mathrm{lb}$ & $\mathrm{kg}$ & 2.2046 \\
1.1209 & $\mathrm{lb} / \mathrm{acre}$ & $\mathrm{kg} \cdot \mathrm{ha}^{-1}$ & 0.8922 \\
444.8222 & $\mathrm{lbf}$ & $\mathrm{cN}$ & 0.0022 \\
28.3495 & $\mathrm{oz}$ & $\mathrm{g}$ & 0.0353 \\
1.1161 & $\mathrm{oz} /$ inch & $\mathrm{g} \cdot \mathrm{mm}^{-1}$ & 0.8960 \\
2.3385 & $\mathrm{qt} / \mathrm{acre}$ & $\mathrm{L} \cdot \mathrm{ha}^{-1}$ & 0.4276 \\
$\left({ }^{\circ} \mathrm{F}-32\right) \div 1.8$ & ${ }^{\circ} \mathrm{F}$ & ${ }^{\circ} \mathrm{C}$ & $\left({ }^{\circ} \mathrm{C} \times 1.8\right)+32$ \\
& & &
\end{tabular}


'Tifblue' and 'Brightwell' rabbiteye blueberry in Georgia, both of which experience high rates of splitting when it rains during fruit ripening, it reportedly reduced fruit splitting (Cultiva, 2018); no other fruit quality traits, such as firmness or berry size, were measured. In 2016, additional trials were performed with biofilm on 'Brightwell', where applications increased marketable fruit yield but did not impact fruit quality or shelf life; no splitting occurred in any treatment due to low rainfall that year (E. Smith, personal communication).

The objectives of this study were to test the biofilm on two highbush blueberry cultivars commonly grown in the Pacific northwestern United States, Elliott and Legacy, to determine the impact on fruit quality. Timing and method of application were evaluated in two separate studies to determine best practices.

\section{Materials and methods}

Two experiments were conducted, the first to study the impact of application timing on the efficacy of the biofilm for increasing fruit firmness, berry size, and yield and the second to study the impacts of application method on treatment efficacy.

EXPT. 1. The trial was conducted in a mature 'Elliott' planting at the North Willamette Research and Extension Center (NWREC), Aurora, OR (lat. $45^{\circ} 28^{\prime} \mathrm{N}$, long. $122^{\circ} 76^{\prime} \mathrm{W}$ ). Plants were spaced $3 \mathrm{ft}$ apart within the row, $10 \mathrm{ft}$ between rows, and were drip irrigated with perennial grass planted in the aisles. Treatments were applied in a randomized complete block design with four replicates with at least one untreated buffer row between treatment rows and at least $10 \mathrm{ft}$ between experimental plots to prevent spray drift from one treatment plot to the next. The tractor was stopped and the sprayer turned off immediately after each plot was treated to ensure that no spray would drift to another plot. Due to an existing trial on the impacts of nitrogen (N) fertilization rate, plants were fertilized with either 50 or $150 \mathrm{lb} /$ acre N. Biofilm treatments were randomly assigned to plots receiving the fertilizer treatments within each block. Previous research in this field showed no differences in yield, berry weight, or firmness due to these differences in $\mathrm{N}$ fertilization (Strik and Buller, 2014). There were 13 to 16 plants per plot, as plants had been removed from some plots in previous years. The number of plants was recorded and used to calculate yield per plant.

Three timings of application were evaluated in addition to a watersprayed control. Treatments were applied with an airblast sprayer (Rears Manufacturing, Coburg, OR) at a rate of $2 \mathrm{qt} /$ acre biofilm in $50 \mathrm{gal} /$ acre water on each application date. The active ingredients of the biofilm are not provided by the manufacturer, so all rates are given as rate of product. Timings included: 1) the label recommendation at the time of the study ["label" (applications at 5- to 10-mm berry size, $10 \%$ to $20 \%$ color change, and between the first and second fruit harvests) ]; 2) the addition of a preharvest timing ["early" (applications at 5- to 10 -mm berry size, $10 \%$ to $20 \%$ color change, and 7 to $10 \mathrm{~d}$ preharvest)]; and 3 ) starting applications later ["late" (applications at 10\% to $20 \%$ color change, 7 to $10 \mathrm{~d}$ preharvest, and between the first and second fruit harvests)]. The control was sprayed with water at every application date when treatments were applied, for a total of four applications. Table 1 shows the dates of treatment application and dates of fruit sampling or harvest. Treatments were applied when temperatures were below $85^{\circ} \mathrm{F}$ to prevent any possible phytotoxicity.

ExPт. 2. The trial was conducted in mature 'Legacy' at a large commercial blueberry farm located near Salem, OR (lat. $45^{\circ} 00^{\prime} \mathrm{N}$, long. $122^{\circ} 56^{\prime} \mathrm{W}$ ). Plants were spaced $3 \mathrm{ft}$ apart within the row, $10 \mathrm{ft}$ between rows and were drip irrigated with a perennial grass planted between the rows. An existing microsprinkler system, used by the grower for chemigation and evaporative cooling if necessary $[15 \mathrm{gal} / \mathrm{h}$ sprinkler heads (Supernet; Netafim USA, Fresno, CA)], was used for this trial. Two methods of application were evaluated: 1) 2 qt/acre applied with an airblast sprayer (Rears Manufacturing) in $50 \mathrm{gal} / \mathrm{acre}$ water, 2) $2 \mathrm{qt} / \mathrm{acre}$ applied via the aforementioned microsprinkler system in $45 \mathrm{gal} / \mathrm{acre}$ water per minute with the system run for 15

Table 1. Dates of biofilm treatment application ["label" [ $2 \mathrm{qt} / \mathrm{acre}\left(4.7 \mathrm{~L} \cdot \mathrm{ha}^{-1}\right)$ applied at 5- to $10-\mathrm{mm}(0.2-0.4 \mathrm{inch})$ berry size, $10 \%$ to $20 \%$ color change, and between the first and second fruit harvests], "early" ( 2 qt/acre applied at 5- to $10-\mathrm{mm}$ berry size, $10 \%$ to $20 \%$ color change, and $7-10 \mathrm{~d}$ preharvest), "late" ( $2 \mathrm{qt} /$ acre applied at $10 \%$ to $20 \%$ color change, $7-10 \mathrm{~d}$ preharvest, and between the first and second fruit harvests), and control (water sprayed) $(n=16)\}$ and fruit sampling for highbush blueberry cultivars Elliott at Oregon State University's North Willamette Research and Extension Center [Aurora, OR (Expt. 1)] and Legacy at a grower collaborator site [Salem, OR (Expt. 2)] in 2017.

\begin{tabular}{|c|c|c|c|c|}
\hline Treatment & Timing & Date applied & Harvest no. & Date \\
\hline & \multicolumn{4}{|c|}{ Expt. 1: Elliott } \\
\hline Label, early & 5 - to 10 - $\mathrm{mm}$ berry size & 25 May & 1 & 9 Aug. \\
\hline Label, early, late & $10 \%$ to $20 \%$ color change & 26 July & 2 & 16 Aug. \\
\hline Label, late & Between first/second harvest & $\begin{array}{l}14 \text { Aug. } \\
\text { Expt. 2: Legacy }\end{array}$ & & \\
\hline Airblast, sprinkler & Between second/third harvest & 10 Aug. & 3 & 11 Aug. \\
\hline \multirow[t]{2}{*}{ Airblast, sprinkler } & Between third/fourth harvest & 24 Aug. & 4 & 25 Aug. \\
\hline & & & 5 & 8 Sept. \\
\hline
\end{tabular}


min, and 3 ) an untreated control (only water applied by airblast). Both treatments were applied four times: at $10 \%$ to $20 \%$ color change, 7 to $10 \mathrm{~d}$ preharvest, between the second and third fruit harvest, and between the third and fourth fruit harvest (Table 1 ). Because the microsprinkler system had to be run in large blocks (over 4 acres), we were unable to replicate spray treatments. Each treatment block was at least 0.5 acre in size, and four 60 -ft-long and 10-ft-wide sections (encompassing plants from both sides of a treated alley) of each block were preselected to serve as replicates for fruit sampling. The grower did not use the microsprinkler system for evaporative cooling in 2017 during our study.

FRUIT HARVEST AND ANALYSIS. Fruit samples were harvested by hand just before each commercial harvest (three machine harvests of 'Elliott' and five hand harvests of 'Legacy'). Timing of harvest was determined using our experience with machine- harvesting of 'Elliott' and by the grower for 'Legacy'. Fruit were picked into $170-\mathrm{g}$ commercial polyethylene containers ["clamshells" (Sambrailo Packaging, Watsonville, CA)] and analyzed on the day of harvest for berry weight, rating of fruit appearance, firmness, skin toughness, and TSS. Fruit appearance was subjectively rated on a 1 to 5 scale, with 1 being the least marketable and 5 being undamaged. All fruit harvested were considered marketable, but aesthetic

Table 2. Machine-harvested yield of highbush blueberry cultivar Elliott (Expt. 1) at Oregon State University's North Willamette Research and Extension Center (Aurora, OR) by harvest and total cumulative yield.

\begin{tabular}{lcccc}
\hline & & \multicolumn{3}{c}{${\text { Yield }(\mathrm{kg} / \text { plant })^{\mathrm{z}}}$} \\
\cline { 2 - 5 } Treatment $^{\mathrm{y}}$ & Harvest $\mathbf{~}$ & Harvest 2 & Harvest 3 & Cumulative yield \\
\hline Control & 1.28 & 0.93 & 1.63 & 3.83 \\
Early & 1.18 & 0.83 & 1.43 & 3.43 \\
Label & 1.23 & 1.00 & 1.39 & 3.62 \\
Late & 1.28 & 0.93 & 1.62 & 3.83 \\
Significance & $\mathrm{NS}$ & $\mathrm{NS}$ & $\mathrm{NS}$ & NS
\end{tabular}

${ }^{\mathrm{z}} 1 \mathrm{~kg}=2.2046 \mathrm{lb}$.

y Control = water sprayed at each date of application; "Early" $=2 \mathrm{qt} /$ acre $\left(4.7 \mathrm{~L} \cdot \mathrm{ha} \mathrm{a}^{-1}\right)$ applied at 5 - to 10 - $\mathrm{mm}(0.2-0.4$ inch $)$ berry size, $10 \%$ to $20 \%$ color change, and $7-10 \mathrm{~d}$ preharvest; "Label" = the current label recommendation of $2 \mathrm{qt} /$ acre applied at 5 - to 10 -mm berry size, $10 \%$ to $20 \%$ color change, and between the first and second fruit harvests; "Late" $=2$ qt/acre applied at $10 \%$ to $20 \%$ color change, $7-10$ d preharvest, and between the first and second fruit harvests.

${ }^{x}$ NS indicates not significant at the $P<0.05$ level. Actual probability values provided where $P<0.1$ to show potential trends in the data.

Table 3. Results of analysis of variance for the impact of biofilm treatment ["label" [ $\left.2 \mathrm{qt} / \mathrm{acre}^{(4.7 \mathrm{~L} \cdot \mathrm{ha}}{ }^{-1}\right)$ applied at 5 - to $10-\mathrm{mm}(0.2-0.4$ inch) berry size, $10 \%$ to $20 \%$ color change, and between the first and second fruit harvests], "early" ( 2 qt/ acre applied at 5- to $10-\mathrm{mm}$ berry size, $10 \%$ to $20 \%$ color change, and $7-10 \mathrm{~d}$ preharvest), "late" ( 2 qt/acre applied at $10 \%$ to $20 \%$ color change, 7-10 d preharvest, and between the first and second fruit harvests), and control (water sprayed) $(\mathrm{n}=16)\}$ on fruit quality parameters for three machine harvests of northern highbush blueberry cultivar Elliott (Expt. 1$)$ on the day of harvest and two subsequent storage dates at Oregon State University's North Willamette Research and Extension Center (Aurora, OR) in 2017.

\begin{tabular}{|c|c|c|c|c|c|c|c|c|}
\hline Treatment & $\begin{array}{c}\text { Yield } \\
(\mathrm{kg} / \text { plant })^{\mathrm{z}}\end{array}$ & $\begin{array}{l}\text { Appearance } \\
\text { rating }(1-5)^{\mathrm{y}}\end{array}$ & TSS (\%) & $\begin{array}{c}\text { Skin } \\
\text { toughness } \\
(\mathrm{cN})^{\mathrm{z}}\end{array}$ & $\begin{array}{c}\text { Berry } \\
\text { wt }(g)^{\mathrm{z}}\end{array}$ & $\begin{array}{c}\text { Firmness } \\
\left(\mathrm{g} \cdot \mathrm{mm}^{-1} \text { deflection }\right)^{\mathrm{z}}\end{array}$ & $\begin{array}{l}\text { Berry diam } \\
(\mathbf{m m})^{\mathrm{z}}\end{array}$ & $\begin{array}{c}\text { Wt loss } \\
(\%) \\
\end{array}$ \\
\hline Control & 1.28 & 5 & 16.3 & 19.4 & 2.4 & 159 & 17.5 & NA \\
\hline Early & 1.18 & 5 & 14.6 & 18.5 & 2.4 & 152 & 17.9 & \\
\hline Label & 1.23 & 5 & 16.1 & 18.8 & 2.4 & 165 & 17.9 & \\
\hline \multicolumn{9}{|c|}{2 wk postharvest } \\
\hline Control & NA & 3.5 & 17.8 & $17.5 \mathrm{a}^{\mathrm{w}}$ & 2.1 & 130 & $16.6 \mathrm{~b}$ & 5.7 \\
\hline Early & & 3.9 & 16.9 & $16.5 \mathrm{ab}$ & 2.2 & 132 & $17.3 \mathrm{a}$ & 5.1 \\
\hline Label & & 4.0 & 16.3 & $16.3 \mathrm{ab}$ & 2.2 & 125 & $17.3 \mathrm{a}$ & 6.0 \\
\hline Late & & 3.8 & 17.3 & $14.8 \mathrm{~b}$ & 2.2 & 136 & $17.1 \mathrm{ab}$ & 4.8 \\
\hline Significance & & NS & NS & 0.0331 & NS & NS & 0.0277 & NS \\
\hline Label & & 2.4 & 18.1 & 17.1 & 2.0 & 121 & 17.0 & 9.5 \\
\hline Late & & 2.1 & 18.5 & 16.0 & 2.0 & 112 & 16.9 & 8.9 \\
\hline Significance & & NS & NS & 0.054 & NS & NS & NS & NS \\
\hline
\end{tabular}

${ }_{\mathrm{z}} \mathrm{l} \mathrm{kg}=2.2046 \mathrm{lb}, \mathrm{l} \mathrm{cN}=0.0022 \mathrm{lbf}, \mathrm{l} \mathrm{g}=0.0353 \mathrm{oz}, \mathrm{l} \mathrm{g} \cdot \mathrm{mm}^{-1}=0.8960 \mathrm{oz} /$ inch, $\mathrm{l} \mathrm{mm}=0.0394$ inch.

${ }^{\mathrm{y}} 5=$ no visual defects, $\mathrm{l}=$ unmarketable based on visual assessment.

${ }^{x} \mathrm{NS}$ indicates not significant at the $P<0.05$ level. Actual probability values provided where $P<0.1$ to show potential trends in the data.

${ }^{\mathrm{w}}$ Means followed by the same letter are not significant different as determined by analysis of variance using Tukey's honestly significant difference test $(P>0.05)$.

TSS $=$ Total soluble solids; NA = not applicable . 
Table 4. Yield and berry quality data from the first machine harvest of highbush blueberry cultivar Elliott (Expt. 1) on the day of harvest and two subsequent storage dates at Oregon State University's North Willamette Research and Extension Center (Aurora, OR).

\begin{tabular}{|c|c|c|c|c|c|c|c|c|}
\hline Treatment $^{\mathrm{z}}$ & $\begin{array}{c}\text { Yield } \\
(\mathrm{kg} / \text { plant })^{\mathrm{y}}\end{array}$ & $\begin{array}{c}\text { Appearance } \\
\text { rating }(1-5)^{x}\end{array}$ & $\begin{array}{c}\text { TSS } \\
(\%)\end{array}$ & $\begin{array}{l}\text { Skin } \\
\text { toughness } \\
(\mathrm{cN})^{\mathrm{y}}\end{array}$ & $\begin{array}{c}\text { Berry } \\
\text { wt }(g)^{y}\end{array}$ & $\begin{array}{c}\text { Firmness } \\
\left(\mathrm{g} \cdot \mathrm{mm}^{-1}\right. \\
\text { deflection })^{\mathrm{y}}\end{array}$ & $\begin{array}{l}\text { Berry diam } \\
(\mathrm{mm})^{\mathrm{y}}\end{array}$ & $\begin{array}{c}\mathrm{Wt} \\
\text { loss (\%) }\end{array}$ \\
\hline \multicolumn{9}{|c|}{ Day of harvest } \\
\hline Early & 1.18 & 5 & 14.6 & 18.5 & 2.4 & 152 & 17.9 & \\
\hline Label & 1.23 & 5 & 16.1 & 18.8 & 2.4 & 165 & 17.9 & \\
\hline \multicolumn{9}{|c|}{2 wk postharvest } \\
\hline Control & NA & 3.5 & 17.8 & $17.5 \mathrm{a}^{\mathrm{v}}$ & 2.1 & 130 & $16.6 \mathrm{~b}$ & 5.7 \\
\hline Early & & 3.9 & 16.9 & $16.5 \mathrm{ab}$ & 2.2 & 132 & $17.3 \mathrm{a}$ & 5.1 \\
\hline Label & & 4.0 & 16.3 & $16.3 \mathrm{ab}$ & 2.2 & 125 & $17.3 \mathrm{a}$ & 6.0 \\
\hline Late & & 3.8 & 17.3 & $14.8 \mathrm{~b}$ & 2.2 & 136 & $17.1 \mathrm{ab}$ & 4.8 \\
\hline Significance & & NS & NS & 0.0331 & NS & NS & 0.0277 & NS \\
\hline Late & & 2.1 & 18.5 & 16.0 & 2.0 & 112 & 16.9 & 8.9 \\
\hline Significance & & NS & NS & 0.054 & NS & NS & NS & NS \\
\hline
\end{tabular}

${ }^{\mathrm{z}} \mathrm{Control}=$ water sprayed at each date of application; "Early" $=2 \mathrm{qt} /$ acre $\left(4.7 \mathrm{~L} \cdot\right.$ ha $\left.^{-1}\right)$ applied at 5 - to 10 - $\mathrm{mm}(0.2-0.4$ inch $)$ berry size, $10 \%$ to $20 \%$ color change, and $7-10 \mathrm{~d}$ preharvest; "Label" = the current label recommendation of $2 \mathrm{qt} /$ acre applied at 5 - to 10 -mm berry size, $10 \%$ to $20 \%$ color change, and between the first and second fruit harvests; "Late" $=2$ qt/acre applied at $10 \%$ to $20 \%$ color change, $7-10 \mathrm{~d}$ preharvest, and between the first and second fruit harvests.

${ }^{\mathrm{y}} \mathrm{l} \mathrm{kg}=2.2046 \mathrm{lb}, \mathrm{l} \mathrm{cN}=0.0022 \mathrm{lbf}, 1 \mathrm{~g}=0.0353 \mathrm{oz}, \mathrm{l} \mathrm{g} \cdot \mathrm{mm}^{-1}=0.8960 \mathrm{oz} / \mathrm{inch}, 1 \mathrm{~mm}=0.0394$ inch.

${ }^{\mathrm{x}} 5=$ no visual defects, $\mathrm{l}=$ unmarketable based on visual assessment.

wS indicates not significant at the $P<0.05$ level. Actual probability values provided where $P<0.1$ to show potential trends in the data.

${ }^{\mathrm{v}}$ Means followed by the same letter are not significant different as determined by analysis of variance using Tukey's honestly significant difference test $(P>0.05)$.

TSS $=$ Total soluble solids; NA = not applicable.
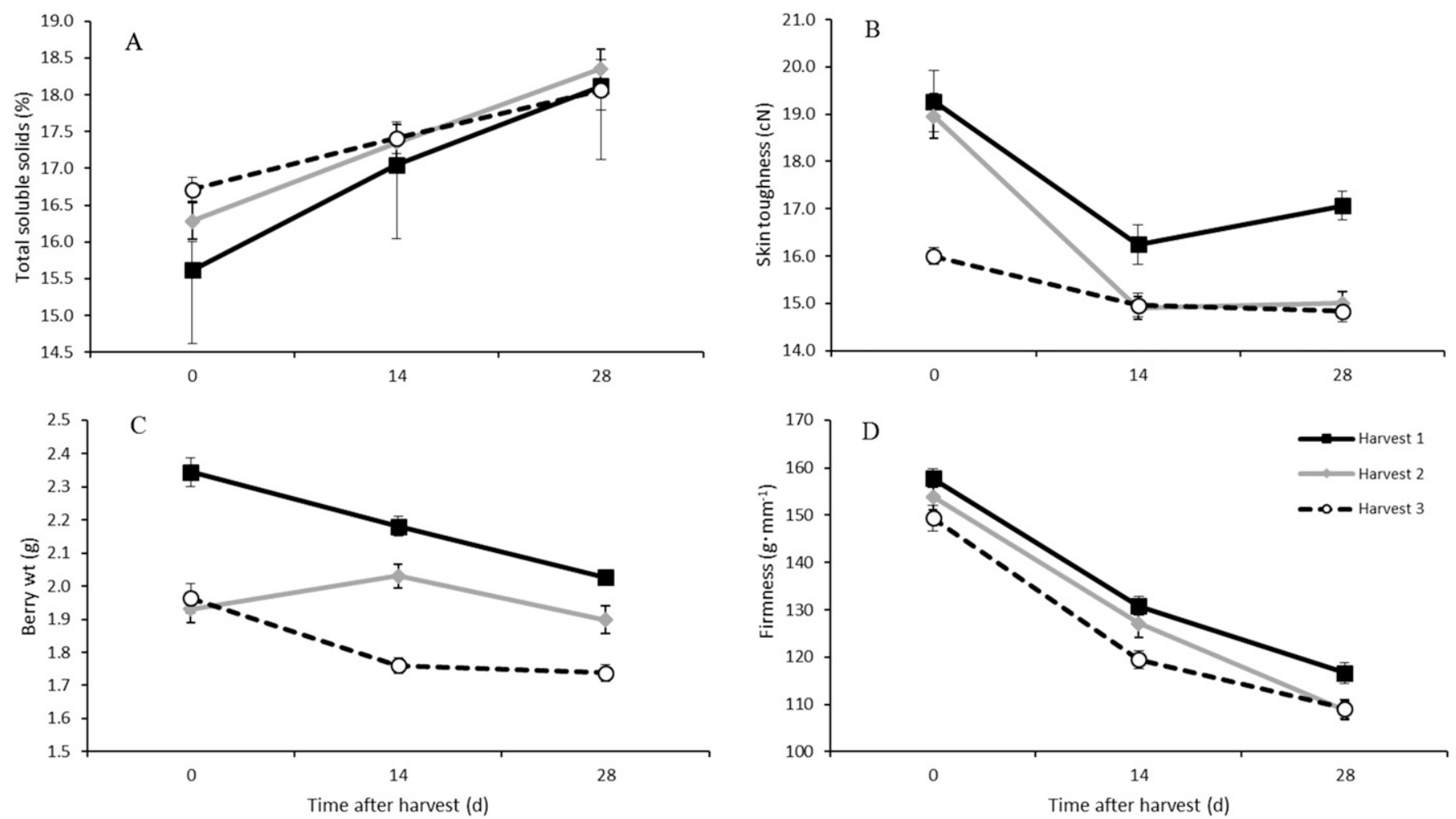

Fig. 1. Fruit (A) total soluble solids (TSS), (B) skin toughness, (C) berry weight, and (D) firmness for each harvest date at 0 (day of harvest), 14 and 28 d postharvest in highbush blueberry cultivar Elliott (Expt. 1) at Oregon State University's North Willamette Research and Extension Center (Aurora, OR), averaged over biofilm treatment $(n=16)$. Error bars represent \pm 1 sE; $1 \mathrm{cN}=0.0022 \mathrm{lbf}, 1 \mathrm{~g}=0.0353 \mathrm{oz}, 1 \mathrm{~g} \cdot \mathrm{mm}^{-1}=0.8960 \mathrm{oz} / \mathrm{inch}$. 
Table 5. Results of analysis of variance for the impact of biofilm application method [ $2 \mathrm{qt} / \mathrm{acre}^{(}\left(4.7 \mathrm{~L} \cdot \mathrm{ha} \mathrm{a}^{-1}\right) \mathrm{product}^{\mathrm{applied}}$ via airblast (in $50 \mathrm{gal} / \mathrm{acre}$ water) or microsprinklers (in $45 \mathrm{gal} / \mathrm{acre}$ water per minute) compared with a water sprayed control $\left.(\mathrm{n}=12) ; \mathrm{gal} / \mathrm{acre}=9.3540 \mathrm{~L} \cdot \mathrm{ha}^{-1}\right]$ on fruit quality parameters for five hand harvests of highbush blueberry cultivar Legacy (Expt. 2) on the day of harvest and two subsequent storage dates at a grower collaborator site (Salem, OR).

\begin{tabular}{|c|c|c|c|c|c|c|c|c|}
\hline Harvest no. & $\begin{array}{l}\text { Appearance } \\
\text { rating } \\
(1-5)^{\mathrm{z}}\end{array}$ & TSS (\%) & $\begin{array}{c}\text { Berry } \\
\text { wt }(g)^{y}\end{array}$ & $\begin{array}{c}\text { Skin } \\
\text { toughness } \\
(\mathrm{cN})^{\mathrm{y}}\end{array}$ & $\begin{array}{c}\text { Firmness } \\
\left(\mathrm{g} \cdot \mathrm{mm}^{-1}\right. \\
{\text { deflection })^{\mathrm{y}}}\end{array}$ & $\begin{array}{c}\text { Berry diam } \\
(\mathrm{mm})^{\mathrm{y}}\end{array}$ & Split berries (\%) & Wt loss (\%) \\
\hline \multicolumn{9}{|c|}{ Day of harvest } \\
\hline Harvest 2 & NS & 0.0658 & NS & NS & NS & NS & NA & \multirow{2}{*}{ NA } \\
\hline Harvest 3 & NS & NS & NS & NS & 0.0691 & 0.054 & NS & \\
\hline & \multicolumn{8}{|c|}{2 wk postharvest (stored at NWREC) } \\
\hline Harvest 1 & NS & NS & NS & NS & NS & NS & NA & 0.0452 \\
\hline Harvest 2 & NS & 0.0295 & 0.0420 & NS & NS & NS & NA & NS \\
\hline Harvest 3 & NS & NS & NS & 0.0163 & NS & 0.0522 & 0.0944 & 0.0016 \\
\hline Harvest 4 & NS & NS & NS & NS & 0.0098 & 0.0424 & 0.0446 & NS \\
\hline Harvest 5 & 0.0963 & NS & NS & NS & NS & NS & NS & 0.0138 \\
\hline Harvest 3 & 0.0723 & NS & NS & 0.0048 & NS & 0.0845 & 0.0621 & NS \\
\hline Harvest 4 & NS & NS & 0.0014 & 0.0001 & NS & NS & 0.0189 & NS \\
\hline Harvest 5 & NS & 0.0264 & NS & NS & NS & NS & NS & 0.0170 \\
\hline & \multicolumn{8}{|c|}{4 wk postharvest (stored at grower facility) } \\
\hline Harvest 1 & NA & NS & NS & NS & 0.0048 & NS & NA & NA \\
\hline Harvest 2 & 0.0963 & NS & 0.0987 & NS & NS & NS & NA & NA \\
\hline Harvest 3 & NS & NS & NS & NS & NS & NS & NS & NA \\
\hline Harvest 4 & NS & NS & NS & NS & NS & NS & NS & NA \\
\hline Harvest 5 & 0.0734 & NS & NS & 0.0207 & NS & NS & NS & NA \\
\hline
\end{tabular}

${ }^{\mathrm{z}} 5=$ no visual defects, $\mathrm{l}=$ unmarketable based on visual assessment.

${ }^{\mathrm{y}} \mathrm{l} \mathrm{g}=0.0353 \mathrm{oz}, \mathrm{l} \mathrm{cN}=0.0022 \mathrm{lbf}, 1 \mathrm{~g} \cdot \mathrm{mm}^{-1}=0.8960 \mathrm{oz} / \mathrm{inch}, \mathrm{l} \mathrm{mm}=0.0394$ inch

${ }^{\mathrm{x}} \mathrm{NS}$ indicates not significant at the $P<0.05$ level. Actual probability values provided where $P<0.1$ to show potential trends in the data.

TSS $=$ Total soluble solids; NA $=$ not applicable; NWREC $=$ North Willamette Research and Extension Center.

defects such as spotting caused by product application, soft fruit, or splitting (in 'Legacy') could contribute to a lower rating. Ten randomly selected berries per experimental unit were used to determine average berry weight and skin toughness [method described in Vance et al. (2017) (Correx 50-g tension gauge; Wagner Instruments, Greenwich, CT)]. These same berries were homogenized to measure TSS using a Palette temperature-compensating digital refractometer (Atago USA, Bellevue, WA). Firmness and berry diameter were measured on 25 berries randomly selected per experimental unit using a fruit firmness tester (FirmTech 2; BioWorks, Wamego, KS). In 'Legacy', the number of split berries out of these 25 was recorded and percent split berries calculated. There were no split berries found in 'Elliott'.

In 'Elliott', machine-harvested yield per plot was measured and divided by the number of plants per plot to determine yield per plant. Cumulative yield was determined by adding the yield per plant from each of three harvests. Total plant yield was not measured in 'Legacy' but was considered commercially acceptable according to grower records.

STORAGE. The impact of treatments on fruit storage ("shelf life") was assessed on additional clamshells that were kept in a walk-in cooler maintained between 34 and $37^{\circ} \mathrm{F}$ for the duration of storage at the NWREC. Samples were analyzed at 2 and 4 weeks after harvest for the same parameters described previously, as well as for percent moisture loss, determined by weighing the clamshell before and after storage. For 'Legacy', separate samples were stored in the same cooler at NWREC and in the grower's cooler facility that was maintained between 32 and $34^{\circ} \mathrm{F}$.

Data ANAlysis. Data were analyzed using PROC MIXED (SAS, version 9.3; SAS Institute, Cary, NC) for a randomized complete block design. Mean comparisons were performed using Tukey's honestly significant difference test. Since different clamshells were analyzed at each storage date; use of repeated measures was not appropriate. PROC UNIVARIATE and the Shapiro-Wilk procedure were used to assess normality of the data. Log transformations were applied where appropriate to improve homogeneity of variance and data were back transformed for presentation.

\section{Results and discussion}

ExPT. 1. There was no consistent impact of biofilm on any measured parameter, including yield (Table 2 ) or fruit quality, before and after storage (Table 3 ). When there was a significant treatment effect on a trait (such as skin toughness on harvest 1 after 2 weeks of storage), the effects were not consistent across harvests or storage times (harvest 1 data are shown in Table 4; data not shown for other harvests). There was no effect of biofilm on fruit appearance rating, positive 
Table 6. Yield and berry quality from the fifth hand harvest of highbush blueberry cultivar Legacy on the day of harvest and subsequent storage dates in Expt. 2 at a grower collaborator site in Salem, OR.

\begin{tabular}{|c|c|c|c|c|c|c|c|c|}
\hline Treatment $^{\mathrm{z}}$ & $\begin{array}{l}\text { Appearance } \\
\text { rating }(1-5)^{\mathrm{y}}\end{array}$ & $\begin{array}{l}\text { TSS } \\
(\%)\end{array}$ & $\begin{array}{c}\text { Berry } \\
\text { wt }(g)^{x}\end{array}$ & $\begin{array}{c}\text { Skin } \\
\text { toughness } \\
(\mathrm{cN})^{\mathrm{x}}\end{array}$ & $\begin{array}{c}\text { Firmness } \\
\left(\mathrm{g} \cdot \mathrm{mm}^{-1}\right. \\
\text { deflection })^{\mathrm{x}}\end{array}$ & $\begin{array}{c}\text { Berry diam } \\
(\mathrm{mm})^{\mathrm{x}}\end{array}$ & $\begin{array}{c}\text { Split } \\
\text { berries (\%) }\end{array}$ & $\begin{array}{c}\text { Wt loss } \\
(\%)\end{array}$ \\
\hline \multicolumn{9}{|c|}{ Day of harvest } \\
\hline Airblast & 4.1 & 15.3 & 1.5 & 15.2 & 207.0 & 14.3 & 43 & \\
\hline Sprinkler & 3.9 & 14.8 & 1.5 & 14.6 & 205.9 & 14.7 & 49 & \\
\hline Significance $^{w}$ & NS & NS & NS & NS & NS & 0.0812 & NS & \\
\hline Treatment & & & & & & & & \\
\hline Control & 4.3 & 15.8 & 1.4 & 16.0 & 205.5 & 14.0 & 35 & $4.4 \mathrm{a}^{\mathrm{v}}$ \\
\hline Airblast & 3.8 & 15.0 & 1.5 & 15.4 & 223.6 & 14.0 & 35 & $4.7 \mathrm{a}$ \\
\hline Sprinkler & 4.1 & 16.2 & 1.5 & 15.4 & 216.8 & 14.3 & 39 & $3.7 \mathrm{~b}$ \\
\hline Significance & 0.0963 & NS & NS & NS & NS & NS & NS & 0.0138 \\
\hline \multicolumn{9}{|c|}{4 wk postharvest (stored at NWREC) } \\
\hline Significance & NS & 0.0264 & NS & NS & NS & NS & NS & 0.017 \\
\hline \multicolumn{9}{|c|}{$4 \mathrm{wk}$ postharvest (stored at grower facility) } \\
\hline Treatment & & & & & & & & \multirow{5}{*}{ NA } \\
\hline Control & 3.4 & 15.2 & 1.3 & $16.2 \mathrm{a}$ & 224.5 & 14.1 & 39 & \\
\hline Airblast & 2.8 & 15.8 & 1.3 & $13.9 \mathrm{~b}$ & 217.2 & 13.7 & 35 & \\
\hline Sprinkler & 3.4 & 15.2 & 1.3 & $14.0 \mathrm{~b}$ & 209.9 & 14.2 & 40 & \\
\hline Significance & 0.0734 & NS & NS & 0.0207 & NS & NS & NS & \\
\hline
\end{tabular}

or negative, from any treatment (harvest 1 data are shown in Table 4; data not shown for other harvests).

As expected, there was no berry splitting in 'Elliott'. During storage, TSS increased as berry weight decreased from moisture loss, whereas skin toughness and firmness generally declined from the day of harvest to 4 weeks in storage (Fig. 1). Berry weight and firmness were greatest on the first harvest and decreased slightly with each subsequent harvest, whereas TSS increased slightly (Fig. 1). After 4 weeks of storage, TSS was similar among all harvest dates.

'Elliott' has a long fruit development period, from late April to midAugust, relative to early-season cultivars such as Duke, which develops from late April to late June. Given the intended timing of biofilm applications at certain growth stages, there was a 2-monthlong period between the first and second application (in the "early" and "label" treatments that were first applied at 5- to 10-mm berry size), but only 9 to $10 \mathrm{~d}$ between the other applications. It is possible that with additional applications during the early fruit developmental stage, the biofilm may have an impact on firmness or other fruit quality characteristics.

Expт. 2. As in Expt. 1, there was no consistent impact of biofilm on 'Legacy' fruit when applied via an airblast or an overhead microsprinkler system when compared with the control (Table 5). Storing fruit in the grower cold storage facility did not result in any different findings than when stored in the NWREC cooler. Table 6 shows an example of measured fruit quality parameters and lack of consistent treatment effects from the fifth harvest.

There were no split berries in the first and second harvest of 'Legacy', but the incidence of splitting increased from the third (16\% of the 25-berry sample) to the fourth $(28 \%)$ and fifth harvests $(41 \%)$. There was very little precipitation after mid-June: $0.3 \mathrm{~mm}$ on 17 July and $2.3 \mathrm{~mm}$ on $13 \mathrm{Aug}$. and no other rainfall until after the final 'Legacy' harvest (U.S. Department of Interior, 2017) The third harvest occurred just before the 13 Aug. rainfall event, indicating that splitting was not only due to rainfall but to other physiological and morphological factors, as discussed by Marshall et al. (2008) in blueberry and Kaiser et al. (2014) in sweet cherry.

Average berry weight declined with each harvest and decreased slightly during storage for all but the first harvest, for which berry weight was maintained during storage (Fig. 2C) and moisture loss was less than in fruit from subsequent harvests (data not shown). Fruit were relatively firm (over $200 \mathrm{~g} \cdot \mathrm{mm}^{-1}$ deflection) throughout the harvest season and after storage. Similarly, skin toughness was consistent during storage, with the first and second harvests having tougher skin than later harvests (Fig. 2).

The application of biofilm at various developmental stages through either an airblast sprayer or microsprinklers was not successful in altering blueberry fruit quality traits in 'Elliott' 

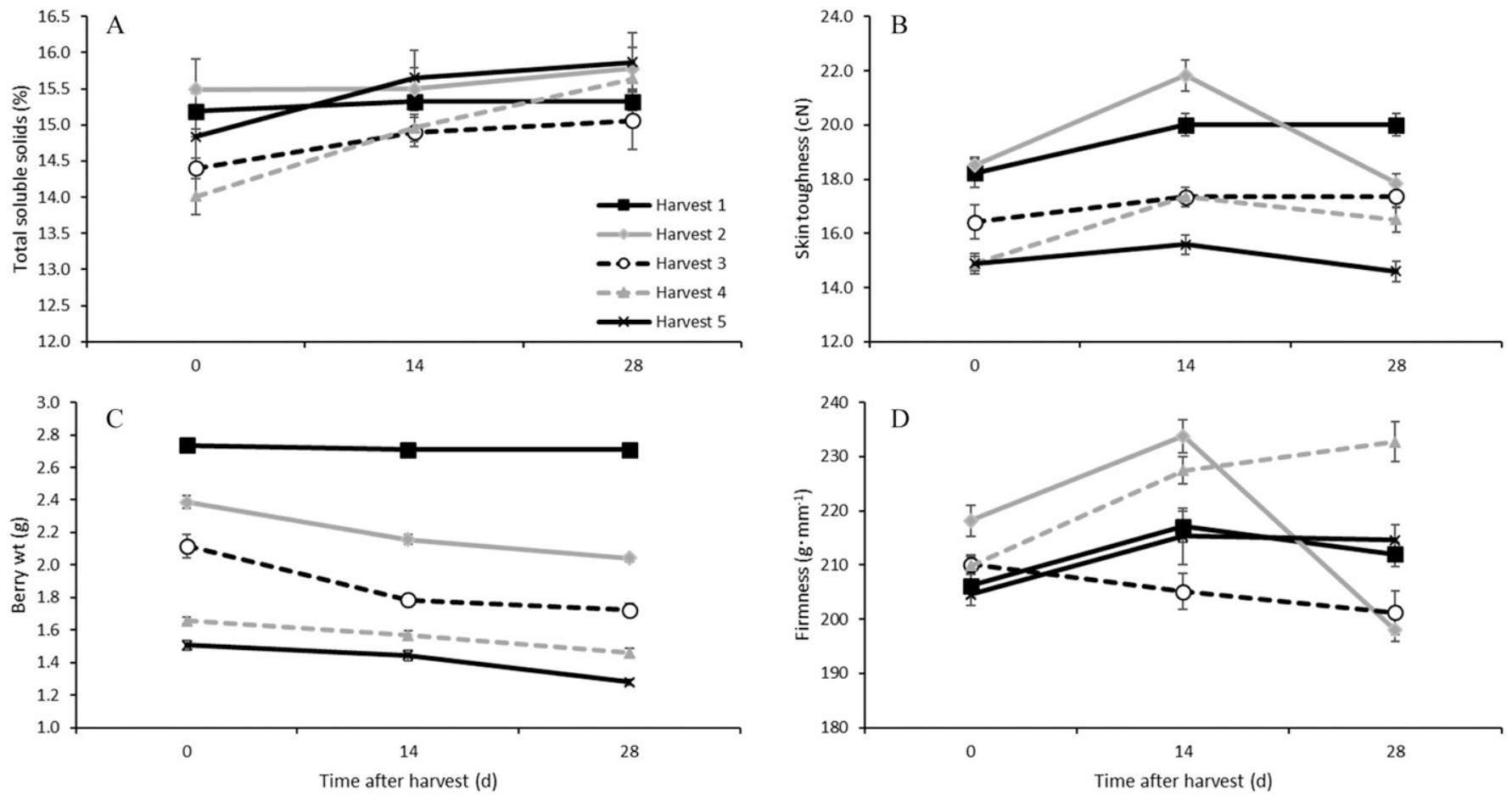

Fig. 2. Fruit (A) total soluble solids (TSS), (B) skin toughness, (C) berry weight, and (D) firmness for each harvest date at 0 (day of harvest), 14, and 28 d postharvest in highbush blueberry cultivar Legacy (Expt. 2) at a grower collaborator site (Salem, OR), averaged over biofilm treatment $(\mathrm{n}=12)$. Error bars represent $\pm 1 \mathrm{sE} ; 1 \mathrm{cN}=0.0022 \mathrm{lbf}, 1 \mathrm{~g}=0.0353 \mathrm{oz}$, $1 \mathrm{~g} \cdot \mathrm{mm}^{-1}=0.8960 \mathrm{oz} / \mathrm{inch}$.

or 'Legacy' or reducing splitting in 'Legacy'. If the product is not effective through an airblast sprayer, which provides thorough coverage to the bushes, it is not likely to be effective through a sprinkler, which does not have the force to penetrate the full mature blueberry canopy. Further testing would be necessary to determine whether applications earlier in the developmental process, or perhaps a different product formulation, could have an impact on fruit quality and splitting.

\section{Literature cited}

Cultiva. 2018. Superior protection starts with Parka. 13 Sept. 2018. <http://www. cultivaipm.com/wp-content/uploads / 2017/03/Parka-Cultiva-English-Brochurefor-Website.pdf $>$.

Ehlenfeldt, M.K. and R.B. Martin, Jr. 2002. A survey of fruit firmness in highbush blueberry and species-introgressed blueberry cultivars. HortScience 37:386-389.

Kaiser, C., E. Fallahi, M. Meland, L.E. Long, and J.M. Christensen. 2014. Prevention of sweet cherry fruit cracking using SureSeal, an organic biofilm. Acta Hort. 1020:477-488.
Marshall, D.A., J.M. Spiers, and J.H. Braswell. 2006. Splitting severity among rabbiteye (Vaccinium ashei Reade) blueberry cultivars in Mississippi and Louisiana. Intl. J. Fruit Sci. 6:77-81.

Marshall, D.A., J.M. Spiers, and S.J. Stringer. 2007. Laboratory method to estimate rain-induced splitting in cultivated blueberries. HortScience 42:1551-1553.

Marshall, D.A., J.M. Spiers, and S.J. Stringer. 2008. Blueberry splitting tendencies as predicted by fruit firmness. HortScience 43:567-570.

Moggia, C., J. Graell, I. Lara, G. Gonzalez, and G.A. Lobos. 2017. Firmness at harvest impacts postharvest fruit softening and internal browning development in mechanically damaged and non-damaged highbush blueberries (Vaccinium corymbosum L.). Front. Plant Sci. 8:535.

Strik, B.C. and G. Buller. 2014. Nitrogen fertilization rate, sawdust mulch, and preplant incorporation of sawdust - Longterm impact on yield, fruit quality, and soil and plant nutrition in 'Elliott'. Acta Hort. 1017:269-276.

U.S. Department of Agriculture. 2017. National Agriculture Statistics Service
NW noncitrus fruit and nut 2016 summary. 25 Jan. 2017. <https://www.nass. usda.gov/Statistics_by_State/Oregon/ Publications/Fruits_Nuts_and_Berries / 2017 /Fruit.pdf>.

U.S. Department of Interior. 2017. Bureau of reclamation, Boise, DI. Agrimet Weather station web site. 22 Jan. 2017. <https://www.usbr.gov/pn/agrimet/ webarcread.html>.

Vance, A.J., P. Jones, and B.C. Strik. 2017. Foliar calcium applications do not improve quality or shelf life of strawberry, raspberry, blackberry, or blueberry fruit. HortScience 52:382-387.

Vorsa, N. 1998. Highbush blueberry varieties. In: The blueberry bulletin Vol. XIV: 20. Rutgers Coop. Ext. p. 2-4. 26 Jan. 2017. <https://njaes.rutgers.edu/ blueberrybulletin/1998/bb-v14n20.pdf>.

$\mathrm{Xu}$, R., F. Takeda, G. Krewer, and C. Li. 2015. Measure of mechanical impacts in commercial blueberry packing lines and potential damage to blueberry fruit. Postharvest Biol. Technol. 110:103-113.

Yang, W.Q., J. Harpole, C.E. Finn, and B.C. Strik. 2009. Evaluating berry firmness and total soluble solids of newly released highbush blueberry cultivars. Acta Hort. 810:863-867. 